гия: символ и архетип. Новосибирск:, 1991. 152 с.

7.Еркинова Р. М. Шаманский мир в рисунках Г.И. Чорос-Гуркина // Вестник Томского университета. 2008. № 316. С. 80-83.

8. Ледебур К. Ф., Бунге А. А., Мейер К. А. Путешествие по Алтайским горам и джунгарской киргизской степи. Новосибирск, 1993. 414 с.

9. Чихачёв П. А. Путешествие в Восточный Алтай. Москва, 1974. 360 с.

10. Мукаева Л. Н. Из истории изучения Горного Алтая П. А. Чихачевым в 1842 г. // Вестник Томского университета. 2011. № 353. С. 110-116.

11. Костров Н. А. Поездка на Чую доктора Радлова в 1860 году. Томск, [1879]. 80 с.

12. Вербицкий В.И. Алтайские инородцы: сборник этнографических статей и исследований алтайского миссионера, протоиерея В.И. Вербицкого. М.: Т-во скоропечатни А.А. Левенсон. 1893. 239 c.

13. Потанин Г.Н. Очерки Северо-Западной Монголии. Результаты путешествия, исполненного в 1879 г. по поручению Императорского Географического общества Г.Н. Потаниным. Вып. IV . Материалы Этнографические. Санкт-Петербург, 1883. $1026 \mathrm{c}$.

14. Мукаева Л. Н. Картина Горного Алтая в отечественной и зарубежной мысли XVIXVIII вв. // Евразийцы. Горно-Алтайск, 2007. С. $41-49$.

15. Гранё Й. Г. Алтай. Увиденное и пережитое в годы странствий. М.: «Индрик», 2012. 608 с.

16. Мукаева Л. Н. Экспедиционные исследования финского геоморфолога Й. Г. Гранё в Северо-Восточном Алтае в начале XX в. // Полевые исследования на Алтае, в Прииртышье и Верхнем Приобье (археология, этнография, устная история): 2017 год. Горно-Алтайск, 2018. С. 156-165.

17. Чевалков М. В. Памятное завещание. Горно-Алтайск, 2007. 131 с.

18. Легенды и мифы Седого Алтая. ГорноАлтайск, 2008. 92 с.

19. Гуркин Г. И. Алтай и Катунь // «Дик и чуден Алтай ...». Горно-Алтайск, 2011. С. 11-13.

20. Мукаева Л. Н. Гора Белуха как природный комплекс и духовно-сакральный символ Алтая // Евразийцы. Горно-Алтайск, 2008. С. 50-54.

21. Костров Н. А. Путешествие доктора Радлова через Алтай к Телецкому озеру и реке Абакану. Томск, $1881.95 \mathrm{c}$.

22. Дьяконова В. П. Алтайцы (материалы по этнографии теленгитов Горного Алтая). ГорноАлтайск, 2001. 221 с.

УДК 338.482.224(571.150-22)

DOI: $10.32340 / 2514-772 X-2020-1-41-44$

С. В. Харламов, кандидат географических наук, доцент Алтайский государственный институт культуры (Барнаул, Россия) harlamovageo@rambler.ru

Н. Ф. Харламова, кандидат географических наук, доцент Алтайский государственный университет (Барнаул, Россия) kharlamova.57@mail.ru

\title{
КУЛЬТУРНО-ИСТОРИЧЕСКОЕ НАСЛЕДИЕ АГРАРНЫХ ТЕРРИТОРИЙ КАК ТУРИСТИЧЕСКИЙ РЕСУРС АЛТАЙСКОГО КРАЯ
}

Аннотация. Увеличение туристского потока требует не только освоения новых природнотерриториальных комплексов территории, но и обширного вовлечения в данную экономическую сферу в качестве туристского ресурсов исторических, социально-культурных и иных объектов туристского интереса. В целях единого учета туристских ресурсов; предоставления туристам (экскурсантам) необходимой информации, обеспечивающей компетентный выбор в сфере туризма; создания благоприятных условий для привлечения инвестиций в туристско-рекреационный и санаторно-курортный комплексы и др. целей для обеспечения устойчивого развития туризма, в 2019-2020 гг. разработано Положение о туристском реестре Алтайского края. На примере Белокурихинско-Ануйской туристско-ресурсной зоны, в состав которой, помимо города-курорта Белокуриха, входят и аграрные Смоленский и Солонешенский районы, выделены исторические туристские ресурсы, которые предлагаются для включения в Реестр туристских ресурсов Алтайского края.

Ключевые слова: туризм, культурно-исторические туристские ресурсы, реестр туристских ресурсов, Алтайский край, устойчивое развитие. 
Аграрная специализация экономики Алтайского края предопределяет преобладание территорий, где осуществляются разнообразные виды сельскохозяйственной деятельности, характерные для внутриконтинентальных пространств умеренных широт. В их пределах сохраняются многочисленные разнообразные материальные и нематериальные объекты культуры народов, проживавших с эпохи раннего палеолита и до современности. Об этом свидетельствуют результаты исследований, проводившихся многими учеными.

Стратегия социально-экономического развития Алтайского края [1] многие десятилетия связана с важнейшей ролью сельского хозяйства. Начиная с 2007 г. в числе приоритетных направлений экономики края была обозначена также и туристская деятельность. Правильность подобного выбора подтверждается основными положениями современной Концепции федеральной целевой программы «Развитие внутреннего и въездного туризма в Российской Федерации (2019 - 2025 годы), согласно которым туризм определен как новый эффективный инструмент социальноэкономического развития Российской Федерации. Туризм вносит существенный вклад в обеспечение устойчивого социально-экономического развития и социальной стабильности, эта отрасль важна для развития малых форм бизнеса и микропредприятий, создания рабочих мест, а также способствует самозанятости населения, обеспечивая высокие стандарты благосостояния человека, экономический и социокультурный прогресс в регионах России [2]. Однако до настоящего времени туристская активность россиян остается пониженной: в среднем лишь $45 \%$ жителей страны в последние 5 лет отдыхали в регионе, отличном от региона проживания. Это свидетельствует о необходимости дальнейшего повышения доступности туристских продуктов для жителей страны и стимулирования мотивации к совершению путешествий [3].

Начиная с советских времен, Алтайский край был достаточно привлекателен для путешественников и туристов, прежде всего, благодаря уникальной природе горных территорий и теплым озерам равнинной части, а также наиболее комфортным в Сибири климатическим условиям.

Природные туристские ресурсы будут попрежнему играть ведущую роль в развитии туризма в Алтайском крае в обозримом будущем. Однако в настоящее время увеличение туристского потока требует не только освоения новых природнотерриториальных комплексов, но и обширного вовлечения в данную экономическую сферу в качестве туристского ресурсов исторических, социально-культурных и иных объектов туристского интереса.
Практика показывает, что далеко не все объекты природного и культурно-исторического наследия, даже имеющие статус памятников природы, археологии, архитектуры и пр., представляют интерес в качестве объектов туристского притяжения.

Практические задачи дальнейшего развития туризма и туристской деятельности в целях устойчивого развития Алтайского края приводят к необходимости в целях территориальной систематизации туристских ресурсов провести районирование (зонирование) территории. Основой предложенного авторами туристского районирования являются два основных блока параметров:

- физико-географическое районирование территории, которое, отражая многообразие природных комплексов, необходимо при проведении оценки функциональных возможностей отдельных районов для развития туризма;

- классификация видов рекреационной деятельности применительно к внутриконтинентальной территории, представленной равниной и горами.

При проведении туристско-ресурсного зонирования учитывалась схема административнотерриториального деления, поскольку в соответствии с нормативно-правовыми требованиями, муниципальные образования, при наличии необходимых ресурсов, вправе организовывать на своей территории различные виды деятельности, в том числе туризм.

В результате осуществленного комплекса исследований [4] для территории Алтайского края выделено 13 туристско-ресурсных зон, в том числе территория г. Барнаула.

В целях единого учета туристских ресурсов; предоставления туристам (экскурсантам) необходимой информации, обеспечивающей компетентный выбор в сфере туризма; создания благоприятных условий для привлечения инвестиций в туристско-рекреационный и санаторно-курортный комплексы и др. целей для обеспечения устойчивого развития туризма, в 2019-2020 гг. разработано Положение о туристском реестре Алтайского края [5], в создании которого также принимали участие и авторы данной статьи. Началось создание новой консолидированной базы данных, включающей два больших тематических раздела: реестр туристских ресурсов и реестр объектов туристской индустрии.

Краткая структура Реестра: Раздел 1. Туристские ресурсы Алтайского края: Подраздел 1.1. «Природные объекты», включающий в себя: 1.1.1. Особо охраняемые природные территории федерального, регионального и местного значения, в том числе государственные природные заповед- 
ники, национальные парки, природные парки, природные государственный заказники, памятники природы. 1.1.2. Другие природные объекты.

Подраздел 1.2. «Исторические объекты», включающий в себя: 1.2.1. Памятники археологии, 1.2.2. Памятники архитектуры. 1.2.3. Памятники истории, и места, связанные с историческими событиями; 1.2.4. Другие исторические объекты. Подраздел 1.3. Социально-культурные объекты, включающие в себя: 1.3.1. Музеи; 1.3.2. Театры; 1.3.3. Парки; 1.3.4. Другие социально-культурные объекты. Раздел 2. Субъекты туристской индустрии Алтайского края.

На примере Белокурихинско-Ануйской туристско-ресурсной зонь [4], в состав которой, помимо города-курорта Белокуриха, входят и аграрные Смоленский и Солонешенский районы, выделены исторические туристские ресурсы, предлагаемые для включения в Реестр туристских ресурсов Алтайского края.

Подраздел 1.2. «Исторические объекты». Раздел 1.2.1. Памятники археологии: Солонешенский район: Денисова пещера - объект, безусловно, имеющий не только федеральное, но и мировое значение [6]; археологическая стоянка Карама в долине р. Ануй; курганные группы в долине р. Ануй; Пещера им. Окладникова; Сибирячихинская пещера. Смоленский район: Зуев ручей, стоянка с. Солоновка, правый берег реки Песчаная, в 0,5 км от пос. Красный Городок; Малышкин лог, могильник; Широкий Лог, поселение; Усть-Быстрая, поселение; Заречное 1 и 2, поселения; Иконниково 1 и 2, стоянка, поселение; Кукушкин Елбан, поселение, курганный могильник; Точилинский Елбан, могильник; Точильное 1-10, поселения; УстьБелокуриха 1 и 3, поселение, курганный могильник. Примечание: стоянки, поселения, курганы, могильники и др. объекты обладают низкими аттрактивными качествами и могут выступать в качестве туристских ресурсов только после проведения работ по музеефикации.

Раздел 1.2.2. Памятники архитектуры: Старая радонолечебница курорта Белокуриха (1938 г.); Магазин купца Рождественского (с. Смоленское); Дом купца Рождественского (с. Смоленское). Раздел 1.2.4. Другие исторические объекты. Памятники воинам, погибшим в годы Великой Отечественной войны (1941-1945 гг.), Гражданской войне и локальных войнах. Памятники известным людям: могила и памятник писателя А. П. Соболева, Аллея Победы (с. Смоленское); Мемориальный комплекс на могиле М. С. Евдокимова (с. ВерхОбское).

Предстоит большая работа, в частности, по выделению из значительного объема сведений об объектах культурно-исторического наследия, находящихся на территории, в том числе, и каждого из аграрных районов, тех объектов, которые представляют интерес как туристских ресурсов. Данное исследование будет иметь большое практическое значение, поскольку большинство из объектов культурно-исторического наследия края либо очень слабо включено в сферу туризма, либо вовсе не используется, однако может иметь значительный эффект при их рациональном освоении.

При проведении данных работ должен учитываться очень важный аспект, связанный с представлением об уровне значимости каждого из туристских объектов. Так, отдельные немногочисленные историко-культурные объекты на территории Алтайского края представляют определенный мировой или российский уровень значимости для туристов и посетителей: например, все, что связано с именем М. Т. Калашникова (Курьинский район), или В. М. Шукшина - село Сростки (Бийский район) и др. Сведения о культурно-исторических туристских ресурсах, в формате Реестра размещенные в открытом доступе на официальном административном ресурсе, предполагают многопрофильное использование:

1) туристами при планировании и осуществлении самостоятельных путешествий/экскурсий по краю;

2) участниками туристского бизнессообщества при создании разнообразных востребованных турпродуктов, формировании стратегии их продвижения и реализации;

3) органами как местной, так и краевой исполнительной и законодательной власти при формировании туристического имиджа каждого из аграрных районов и Алтайского края в целом.

В настоящее время преобладающая часть объектов из числа туристских ресурсов, включая и культурно-историческое наследие, востребованы туристами в основном из различных субъектов Сибирского Федерального округа, и включение их в Реестр будет иметь заметный положительный эффект при формировании оригинальных популярных турпродуктов: экскурсионных и туристских программ.

\section{Список литературы}

1. Об утверждении стратегии социальноэкономического развития Алтайского края до 2025 года : закон Алтайского края от 21 нояб. 2012 г. № 86-3C. URL: http://www.econom22.ru/upload/iblock/ f3c/zakon86-zs_121121.pdf(08.11.2020).

2. Концепция федеральной целевой программы «Развитие внутреннего и въездного туризма в Российской Федерации (2019 - 2025 годы)»: утв. распоряжением Правительства Российской Федерации от 5 мая 2018 г. № 872-р. 
URL: http://www.consultant.ru/document/cons_doc LAW_297883/eda905a41f65bd305620f5084992c8e98 $67 \mathrm{fc} \overline{\mathrm{dd}} /(08.11 .2020)$.

3. Стратегия развития туризма в Российской Федерации на период до 2035 года : утв. распоряжением Правительства Российской Федерации от 20 сент. 2019 г. № 2129-p. URL: http:// government.ru/docs/37906/ (25.09.2020).

4. Харламов С. В. Туристское регионоведение. Алтайский край: учебное пособие. Барнаул: Изд-во Алт. гос. акад. Культуры и искусств, 2015. $263 \mathrm{c}$.
5. Положение о туристском реестре Алтайского края: утр. постановлением Правительства Алтайского края от 27 авг. 2020 г. № 363. URL: http://docs.cntd.ru/document/570911208 (08.11.2020).

6. Харламов С. В., Харламова Н. Ф. К вопросу о создании природно-археологического парка в Солонешенском районе Алтайского края // Учёные записки (Алтайская государственная академия культуры и искусств). 2018. № 3. С. 83-93. 